\title{
Teknik Marmet terhadap Kelancaran Asi pada Ibu Post Partum
}

\author{
Wasis Pujiati ${ }^{1}$, Lili Sartika², Liza Wati ${ }^{3}$, R Alya Ramadinta ${ }^{4}$ \\ 1,2,3,4 STIKES Hang Tuah Tanjungpinang \\ wasispujiati82@gmail.com* \\ *Corresponding author
}

\begin{tabular}{l}
\hline Informasi artikel \\
Sejarah artikel: \\
Received: $12-10-2021$ \\
Revised: $18-11-2021$ \\
Accepted: $29-11-2-2021$ \\
\hline Kata kunci: \\
Kelancaran Asi, Post \\
partum. Teknik marmet
\end{tabular}
\begin{abstract}
ABSTRAK
Air susu ibu adalah cairan yang di produksi ibu sebagai asupan makanan terbaik bagi kebutuhan gizi bayi. Beberapa permasalahan terkait dengan pemberian ASI pada ibu post partum adalah managemen laktasi yang kurang efektif di hari pertama kelahiran, disebabkan oleh kurangnya pengetahuan dan stress. Salah satu metode yang digunakan untuk mengatasi ketidaklancaran ASI adalah dengan teknik marmet. Teknik marmet merupakan kombinasi pijat yang efektif, manual, aman dan tanpa biaya. Teknik marmet merupakan upaya yang optimal untuk merangsang hormon oksitosin dan prolaktin dalam kelancaran ASI. Tujuan penelitian ini adalah mengetahui pengaruh teknik marmet terhadap kelancaran ASI pada ibu post partum di Wilayah Kerja Puskesmas Kota Tanjungpinang. Merupakan penelitian dengan desain eksperimen semu (Quasi Eksperimen) dengan rancangan Pre and Post Test without Control. Populasi penelitian adalah ibu post partum sebanyak 201 orang dan jumlah sampel sebanyak 30 responden. Sampel diambil menggunakan purposive sampling. Uji hipotesis menggunakan non parametric dengan melakukan uji Wilcoxon. Hasil penelitian didapatkan bahwa ada pengaruh teknik marmet terhadap kelancaran ASI pada ibu post partum dengan nilai $\rho$ value 0,000. Rekomendasi penelitian teknik marmet efektif dilaksanakan untuk melancarkan ASI pada ibu post partum dan teknik marmet dapat merangsang peningkatan hormon prolaksin dan oksitosin berefek relaksasi pada ibu post partum.
\end{abstract}

Key word:

Smooth Breastfeeding, Post partum. Marmet technique

\section{ABSTRACT}

Breast milk is a liquid produced by mothers as the best food intake for the nutritional needs of babies. Several problems related to breastfeeding in post partum mothers are lactation management which is less effective on the first day of birth, caused by lack of knowledge and stress. One of the methods used to overcome breast milk insufficiency is the marmet technique. Marmet technique is a combination of massage that is effective, manual, safe and free of cost. The marmet technique is an optimal effort to stimulate the hormones oxytocin and prolactin in the smooth flow of breast milk. The purpose of this study was to determine the effect of the marmet technique on the smoothness of breastfeeding in post partum mothers in the Tanjungpinang City Health Center Work Area. This is a study with a quasi-experimental design (Quasi Experiment) with a Pre and Post Test without Control design. The research population was post partum mothers as many as 201 people and the number of samples was 30 respondents. Samples were taken using purposive sampling. Hypothesis test using non parametric by doing Wilcoxon test. The results showed that there was an effect of the marmet technique on the smoothness of breastfeeding in post partum mothers with a value of 0.000 . Research recommendations for effective marmet techniques are carried out to launch breast milk in postpartum mothers and the marmet technique can stimulate an increase in the hormones prolaksin and oxytocin so that it has a relaxing effect on postpartum mothers. 


\section{PENDAHULUAN}

Proses persalinan merupakan hal yang lazim terjadi pada ibu hamil yang sudah cukup bulan (37-42 minggu). Keluarnya bayi kedunia melalui proses yang panjang berupa kontraksi otot rahim disertai dengan pembukaan leher rahim (serviks) secara bertahap dilanjutkan dengan otot panggul ibu akan mendorong bayi dan plasenta keluar melalui vagina dengan tidak adanya komplikasi akibat melahirkan yang berdampak buruk seperti kematian pada ibu dan bayi (Rokhamah, 2019). Kematian dan kesakitan pada ibu dan bayi merupakan masalah besar yang harus ditangani khusunya di negara-negara berkembang, sekitar 25-50\% kematian ibu pada masa post partum menjadi faktor utama mortalitas perempuan (WHO, 2015). Faktor penyebabnya akibat komplikasi post partum diantaranya perdarahan, infeksi, hipertensi, abortus dan komplikasi saat kehamilan (WHO, 2014).

Periode post partum merupakan masa yang dilewati ibu melahirkan dimulai dari hari kelahiran pertama sampai 6 minggu kelahiran. Pada tahap ini adanya perubahan fisik, alat reproduksi, perubahan psikologis menghadapi penambahan keluarga baru dan masa laktasi atau menyusui (Rumini et al., 2019). Bayi baru lahir sangat penting mendapatkan perawatan yang maksimum (termasuk pemberian makanan). Asupan yang optimal memenuhi kebutuhan gizi bayi adalah ASI, karena ASI berperan penting dalam tumbuh kembang bayi, selain ASI tidak ada asupan makanan terbaik dikonsumsi bayi baru lahir (Hamidah, 2016). ASI adalah protein, laktosa, dan sejumlah besar lemak dalam larutan garam organik dipecah menjadi partikel, yang berfungsi sebagai jalur transmisi kelenjar payudara ibu (Walyani, 2015). Menurut Peraturan Pemerintah Nomor 33 Tahun 2012 tentang Pemberian ASI eksklusif, Air Susu Ibu (ASI) merupakan cairan hasil sekresi kelenjar payudara.

Setiap ibu yang melahirkan wajib memberikan ASI eksklusif kepada bayi yang dilahirkan kecuali terdapat indikasi medis, ibu tidak ada (meninggal) atau ibu terpisah dari bayi. Pemberian ASI juga berdampak positif bagi ibu seperti mempercepat pemulihan post partum, perlindungan kesehatan ibu seperti kanker payudara dan kanker ovarium, penurunan berat badan, serta mengurangi stress yang memancing hormon oksitosin yang menimbulkan rasa rileks (Dwi et al., 2019). World Health Organitation (WHO) dan United Nation International Children's Emergency Fund (UNICEF) menganjurkan bayi baru lahir sampai usia bayi 6 bulan hanya mengkonsumsi ASI tanpa cairan atau makanan lain kecuali suplemen vitamin, mineral, dan atau obat-obatan untuk keperluan medis dilanjutkan sampai bayi berusia dua tahun dengan makanan pendamping ASI. Agar pemberian ASI eksklusif bertahan sampai 6 bulan WHO merekomendasikan agar ibu memberikan inisiasi dalam satu jam pertama kehidupan bayi hanya menerima ASI dan tidak menggunakan botol atau dot (WHO, 2018) Berdasarkan laporan Global Breastfeeding Scorecard data menyusui dari 193 negara. 170 Negara $(<40 \%)$ bayi tidak mencukupi ASI eksklusif dan 23 negara (>60\%) bayi mencukupi pemberian ASI eksklusif (UNICEF, 2017), terdapat masalah yang dihadapi dunia berupa $37 \%$ bayi mengalami stunting diakibatkan buruknya praktik pemberian ASI eksklusif. Data nasional bayi yang mendapatkan ASI eksklusif tahun 2020 sebesar (69,62\%) angka tersebut tergolong mencukupi target Renstra tahun 2020 (BPS, 2021). Pencapaian presentasi tertinggi cakupan pemberian ASI pada Provinsi Daerah Istimewa Yogyakarta (78,93\%) sedangkan presentasi terendah terdapat pada Provinsi Kalimantan Tengah (52,98\%), pencapaian tersebut masih memiliki masalah internal (fisik, psikologis, inisiasi menyusui dini, pekerjaan ibu dan pendidikan ibu) dan eksternal (keluarga, ketahanan pangan, geografis, peran media, air atau kebersihan sanitasi, professional kesehatan, kemiskinan, keyakinan atau praktik budaya, dan keterlibatan pemerintah) (BPS, 2021).

$$
\text { Pemberian ASI eksklusif }
$$

berdasarkan data badan pusat statistik Provinsi Kepulauan Riau tahun 2019 meningkat dibandingkan dengan cakupan $2018(44,5 \%)$ menjadi $56,5 \%$ pada tahun 2019. Cakupan tertinggi pemberian ASI eksklusif di Provinsi Kepulauan Riau adalah Kabupaten Natuna $(64,6 \%)$ dan terendah di Kabupaten Kepulauan Anambas (22,6\%) serta presentase pemberian ASI eksklusif di Kota Tanjungpinang $(52,8 \%)$ secara umum 4 Kabupaten lainnya melebihi target Renstra (46,5\%) namun Kabupaten Kepulauan Anambas masih dibawah target (Dinas Kesehatan Kabupaten Se-Provinsi Kepulauan Riau, 2019). Adapun faktor 
tambahan kegagalan menyusui yang sering disebabkan karena psikologis ibu pada hari awal proses menyusui, Ibu merasa cemas jika ASI yang dihasilkan tidak mencukupi kebutuhan bayi serta tidak lancar (Setianingrum et al., 2018).

Berdasarkan fenomena didapatkan bahwa banyak pemberian ASI di hari pertama terhambat dikarenakan kelancaran produksi dan ejeksi ASI kurang efektif yang dibuktikan dari 34,5\% melakukan IMD kurang dari 1 jam dan 13\% melakukan IMD kurang dari 48 jam (BPS, 2020). Pemberian ASI kurang dari setengah jam pasca persalinan dapat mencegah penurunan hormon prolaktin dalam peredaran darah ibu sehingga kolostrum pada hari pertama lebih cepat keluar. Bayi tidak menghisap puting susu pada satu jam setelah persalinan maka hormon prolaktin akan menurun dan sulit merangsang prolaktin sehingga produksi ASI kurang lancar dan ASI baru akan keluar pada hari ketiga atau lebih (Yundelfa, M. et al., 2018). Penyebab sedikitnya produksi ASI setelah melahirkan berupa minimnya rangsangan hormon prolaktin yang berperan dalam kelancaran produksi ASI (Aprilina, 2016). Adapun upaya yang dilakukan dalam mengatasi permasalahan ASI secara faramakologi berupa metoklopramid, domperidon dan Chlorpromazin sedangkan secara non farmakologinya yaitu pijat oksitosin, pijat akupresur, endorprin, kompres hangat, perawatan payudara dan teknik marmet (Putri dan Utami, 2020).

Jika masalah menyusui di awal kelahiran tidak dapat diatasi, alternatif yang dapat dilakukan adalah memerah atau memompa ASI 10-20 menit tiap dua sampai tiga jam sekali hingga bayi dapat menyusui. Upaya ini dapat merangsang produksi prolaktin dan mengurangi efek samping dari ketidaklancaran menyusui pada bayi (Widiastuti, et al 2015). Teknik memerah ASI menggunakan tangan disebut teknik marmet. Teknik marmet merupakan kombinasi pijat yang bertujuan melancarkan keluarnya ASI secara manual dan membantu refleks pengeluaran susu (Milk Ejection Reflex). Teknik Marmet merupakan metode pembaharuan pijat dan stimulasi untuk membantu kunci reflek keluarnya ASI. Teknik marmet adalah salah satu cara yang aman dan signifikan dalam merangsang payudara memproduksi lebih banyak ASI (Titisari, 2016). Penelitian yang dilakukan oleh Maryam, et al (2020) yang berjudul Pijat Marmet Sebagai Solusi Kelancaran Produksi Asi Ibu Menyusui Di Kecamatan Sikur Kabupaten Lombok Timur didapatkan hasil ada pengaruh pemberian terapi pijat marmet terhadap peningkatan produksi ASI dengan $p$ value 0,000 . Berdasarkan penelitian yang dilakukan oleh Ningrum, et al (2017) yang berjudul Pengaruh Pemberian Teknik Marmet Terhadap Kelancaran Produksi ASI pada Ibu Post Partum di BPM Wilayah Kerja Puskesmas Sukorame Kota Kediri didapatkan ada pengaruh pemberian teknik marmet terhadap produksi ASI pada ibu post partum di BPM wilayah kerja Puskesmas Sukorame Kota Kediri.

Pada penelitian ini berdasarkan data Tahun 2019 pencapaian target Renstra tentang ASI ekslusif di Kepulauan Riau didapatkan cukup tetapi banyak ibu masih memiliki masalah dalam pemberian ASI eksklusif baik segi internal maupun eksternal seperti kurang pengetahuan terkait pemberian ASI eksklusif, prosedur menyusui secara tepat, manfaat ASI, dampak pemberian ASI yang salah serta pemikiran ibu memberikan susu formula akibat ASI tidak lancar (Dinas Kesehatan Kabupaten Se-Provinsi Kepulauan Riau, 2019), maka pada penelitian ini akan dilaksanakan edukasi dan breast care terlebih dahulu sebelum melakukan pijatan dengan teknik marmet. Penelitian ini hanya difokuskan pada satu kelompok intervensi tanpa kontrol. Jadi diharapkan mendapatkan data tentang pengaruh teknik marmet terhadap kelancaran ASI pada ibu. Berdasarkan studi pendahuluan dari bagian pemegang program KIA di Dinas Kesehatan Provinsi Kepulauan Riau didapatkan bahwa sebagian besar (35\%) ibu melahirkan di Wilayah kerja Puskesmas Kota Tanjungpinang. Berdasarkan hasil wawancara bagian pemegang KIA Puskesmas Kota Tanjungpinang pada hari selasa, 30 Maret 2021 didapatkan 201 ibu post partum. Hasil wawancara dan pengisian penyebaran kuesioner berupa Google Form yang dilakukan peneliti terhadap 6 responden ibu post partum diambil sesuai kriteria, didapatakan sebagian besar (67\%) ibu post partum tidak membersihkan puting susu setelah menyusui, sedangkan (67\%) ibu menyatakan bayi menyusui tidak lebih dari 8 kali dan (67\%) ibu menyatakan bayinya tidak tertidur 3 sampai 4 jam setelah menyusui, serta (83\%) ibu menyatakan bahwa setelah 
menyusui payudara masih terasa tegang. Hasil wawancara dengan ibu post partum bahwa keseluruhan menyatakan tidak mengetahui teknik marmet dan belum pernah melakukan teknik marmet.

\section{METODE PENELITIAN}

Penelitian ini merupakan penelitian kuantitatif dengan jenis pendekatan studi eksperimen semu (Quasi Eksperimen) dengan menggunakan rancangan Pre and Post Test without Control, tipe penelitian ini adalah meneliti tanpa adanya perbandingan atau kelompok yang harus di kontrol. Populasi target pada penelitian ini adalah seluruh ibu post partum Wilayah Kerja Puskesmas Kota Tanjungpinang berjumlah 201 orang. Teknik sampel yang digunakan pada penelitian ini menggunakan Purposive Sampling pengambilan sampel yang dilakukan berdasarkan pertimbangan tertentu yang ditentukan peneliti (Notoadmodjo, 2018). Jumlah sampel sebanyak 30 responden. Tempat yang digunakan dalam penelitian ini di Wilayah Kerja Puskesmas Kota Tanjungpinang. Instrumen penelitian yang digunakan dalam penelitian ini adalah kuesioner yang berisi skor kelancaran ASI.

penelitian ini dilakukan dengan memberikan kuesioner sebelum intervensi, dilakukan intervensi selama 3 hari dan diberikan kuesioner setelah dilakukan intervensi. Analisa data yang digunakan adalah analisis univariat yang dilakukan terhadap tiap variabel dari hasil penelitian, menampilkan distribusi frekuensi dan persentase karakteristik responden, variabel kelancaran ASI. Analisis bivariat yang dilakukan terhadap dua variabel untuk mengetahui perbedaan pengaruh variabel independen (teknik marmet) variabel dependen (kelancaran ASI). hasil data merupakan data non parametric dengan ketentuan berupa skala data ordinal dan jumlah responden $\leq 30$. Uji yang digunakan adalah uji Wilcoxon.
HASIL DAN PEMBAHASAN

Tabel 1

Karakteristik Umum Responden

\begin{tabular}{lcc} 
Karakteristik & $\boldsymbol{f}$ & (\%) \\
\hline Usia & & \\
\hline$<30$ & 17 & 57 \\
\hline$>30$ & 13 & 43 \\
\hline Pendidikan & & \\
\hline SD & 4 & 13 \\
\hline SMP & 5 & 17 \\
\hline SMA & 9 & 30 \\
\hline PT & 12 & 40 \\
\hline Pekerjaan & & \\
\hline Bekerja & 18 & 60 \\
\hline Tidak Bekerja & 12 & 40 \\
\hline Paritas & & \\
\hline Primipara & 12 & 40 \\
\hline Multipara & 18 & 60 \\
\hline Jenis Persalinan & & \\
\hline Normal & 23 & 77 \\
\hline Caesar & 7 & 23 \\
\hline Total & 30 & 100
\end{tabular}

Berdasarkan tabel 1 frekuensi karakteristik responden lebih separuh berada pada rentang usia < 30 tahun (57 \%). Rentang pendidikan sebagian besar perguruan tinggi (40\%). Pekerjaan lebih separuh memiliki pekerjaan (60 \%). Paritas lebih separuh multipara (60 \%). Mayoritas responden bersalin normal (77\%).

Tabel 2

Intensitas kelancaran ASI Sebelum dan sesudah intervensi

\begin{tabular}{lcccccc}
\hline Kelancar & \multicolumn{2}{c}{ Pre Test } & \multicolumn{3}{c}{ Post test } \\
\cline { 2 - 7 } an ASI & $F$ & $(\%)$ & $F$ & $(\%)$ \\
\hline $\begin{array}{l}\text { Lancar } \\
\text { (>75\%) }\end{array}$ & 4 & 13 & $\%$ & 26 & 86 & $\%$ \\
\hline $\begin{array}{l}\text { Cukup } \\
(56 \%-\end{array}$ & 6 & 20 & $\%$ & 2 & 7 & $\%$ \\
$\begin{array}{l}\mathbf{7 4} \%) \\
\text { Tidak }\end{array}$ & 20 & 67 & $\%$ & 2 & 7 & $\%$ \\
$\begin{array}{l}\text { Lancar } \\
\text { (<55\%) }\end{array}$ & & & & & & \\
\hline Total & 30 & $100 \%$ & 30 & $100 \%$ \\
\hline Total
\end{tabular}

Berdasarkan tabel 2 diatas diperoleh intensitas data kelancaran ASI sebelum intervensi dari 30 responden diketahui lebih separuh (67 \%) mengalami ketidaklancaran pemberian ASI dan setelah dilakukan intervensi mengalami peningkatan 
kelancaran pemberian ASI dengan mayoritas (86 \%) lancar dalam pemberian ASI.

\section{Tabel 3}

Perbedaan intensitas kelancaran ASI Sebelum dan sesudah intervensi

\begin{tabular}{lllllc}
\hline Kelancaran ASI & Mean & Std.dev & Min & Max & $\boldsymbol{\rho}$ value \\
\cline { 1 - 4 } Pre Test & 11,13 & 2,177 & 8 & 15 & \multirow{2}{*}{0,000} \\
\cline { 1 - 3 } & 16,27 & 2,227 & 10 & 19 & \\
\hline
\end{tabular}

Berdasarkan tabel 3 didapatkan data bahwa adanya pengaruh yang signifikan teknik marmet terhadap kelancaran ASI pada ibu post partum di wilayah kerja Puskesmas Kota Tanjungpinang dengan nilai rata-rata sebesar 11,3 dengan standar deviasi 2, 177. Sedangkan rata-rata nilai sesudah dilakukan intervensi sebesar 16, 27 dengan standar deviasi 2, 227, dan nilai $\rho$ value adalah 0,000 . Kesimpulannya adalah jika $0,000<$ 0,05 maka $\mathrm{H}_{0}$ ditolak, artinya adanya pengaruh teknik marmet terhadap kelancaran ASI pada ibu post partum di wilayah kerja Puskesmas Kota Tanjungpinang.

\section{PEMBAHASAN}

Berdasarkan karakteristik usia dari 30 responden dalam penelitian ini didapatkan hasil lebih separuh usia $<30$ tahun (57 \%) dan > 30 tahun (43\%). Usia merupakan salah satu faktor yang mempengaruhi kelancaran ASI. Ibu yang memiliki usia matang memberikan dampak yang positif dengan pemikiran dewasa dengan memberikan hal yang terbaik untuk bayi agar tumbuh kembangnya secara optimal dikarenakan semakin bertambah usia seseorang maka semakin tinggi tingkat psikologis dan mentalnya (Widiastuti,dkk 2015). Hal ini sesuai dengan penelitian yang dilakukan Sari, dkk tahun 2016 tentang Hubungan Stres Psikologis Dengan Kelancaran Produksi Asi Pada Ibu Primipara Yang Menyusui Bayi Usia 1-6 Bulan Di Wilayah Kerja Puskesmas Sukorambi yang menyebutkan faktor-faktor yang dapat mempengaruhi produksi ASI salah satunya adalah fisik ibu, yang di dalamnya terdapat status kesehatan ibu, nutrisi dan asupan cairan ibu, merokok, alkohol, umur dan paritas, bentuk dan kondisi puting susu, dan nyeri.

Berdasarkan karakteristik pendidikan dari 30 responden dalam penelitian ini sebagian besar pendidikan responden perguruan tinggi (40\%), SMA
(30\%), SMP (17\%) dan SD (13 \%). Hal ini ada hubungan dengan penelitian Widiastuti,dkk tahun 2015 menyatakan bahwa pendidikan merupakan salah satu faktor terpenting yang mempengaruhi kelancaran ASI dikarenakan pendidikan sebagai wahana menambah ilmu pengetahuan ibu dimana jika ibu memiliki pendidikan tinggi diharapkan pencapaian kepahaman yang optimal dengan memiliki wacana terhadap pengetahuan ibu sehingga terbentuklah pemikiran yang positif, semakin tinggi pendidikan ibu maka semakin banyak informasi yang meningkatkan pengetahuan ibu terhadap kelncaran asi karena ibu mampu menerima parubahan untuk meningktakan kesehatan ibu dan bayi. Ibu memiki motivasi mencari informasi sehingga menambah pengetahuan dan kemapuan terkait laktasi. Tingkat pengetahuan dan pemahaman yang tinggi diharapkan dapat mengalami peningkatan kesadaran dan kemampuan dalam manajemen diri dan waktu serta manajemen laktasi sehingga produksi ASI lancar dan mampu memaksimalkan pemberian ASI.

Berdasarkan karakteristik pekerjaan dari 30 responden dalam penelitian ini sebagian besar pekerjaan responden yang memiliki pekerjaan (60\%) dan yang tidak memiliki pekerjaan (40 \%). Hasil penelitian Sutama tahun 2020 menyatakan ibu yang memiliki pekerjaan lebih aktif mencari informasi dari berbagai sumber mengenai cara pemberian ASI pada saat ibu sedang bekerja. Ketika ibu bekerja, pengasuh yang mendampingi bayi bisa memberikan ASI yang disimpan oleh ibu tanpa pemberian susu formula dan dilanjutkan dengan pemberian ASI secara langsung ketika ibu sudah pulang dari bekerja, sehingga bayi masih bisa mendapatkan ASI. Berdasarkan karakteristik paritas dari 30 responden dalam penelitian ini lebih separuh paritas responden ibu multipara (60\%) dan ibu primipara (40\%). Status paritas terbesar 
adalah multipara didukung dengan penelitian yang dilakukan Astuti tahun 2015 menyatakan bahwa paritas mendeskripsikan jumlah kelahiran pada setiap ibu. Produksi ASI sangat berpengaruh terhadap paritas ibu sehingga berpengaruh juga dengn kelancaran pemberian ASI ibu pada bayi. Ibu multipara dapat mempengaruhi pengetahuan ibu tentang kelancaran ASI dan mencari informasi berdasarkan pengalaman sebelumya.

Berdasarkan karakteristik jenis persalinan dari 30 responden dalam penelitian ini mayoritas jenis persalinan responden normal (77\%) dan Caesar (23\%). Pada penelitian Rosmawati dan sukarta tahun 2018 menyatakan ada hubungan yang berarti antara jenis persalinan dan kelancaran ASI yang akan mempengaruhi riwayat kelancaran ASI, hasil menunjukkan persalinan section Caesar sekitar $70.6 \%$ produksi ASI tidak lancar. Hasil penelitian yang dilakukan didapatkan hasil data sebelum dilakukan intervensi terhadap 30 responden. Diketahui yang memiliki intensitas tidak lancar (67\%), intensitas cukup lancar (20\%) dan intensitas lancar (13 \%). Data hasil penelitian sebelumnya yang dilakukan Dahlan tahun 2017 menyatakan bahwa tidak adanya pengaruh kelancaran ASI sebelum dilakukan intervensi dikarenakan tidak adanya usaha yang dilakukan responden terhadap masalah sehingga ASI pada ibu tidak lancar dan sebagian kecil ibu menggunakan susu formula tanpa pemberian ASI.

Sesudah intervensi hasil penelitian yang dilakukan didapatkan hasil data sesudah dilakukan intervensi terhadap 30 responden. Diketahui intensitas lancar (86 $\%)$, intensitas cukup lancar (7 \%) dan intensitas tidak lancar (7 \%). Hasil penelitian yang dilakukan Sinulingga tahun 2017 menyatakan bahwa ada pengaruh pemberian teknik marmet terhadap kelancaran ASI pada ibu post partum karena teknik memerah ASI menggunakan tangan disebut teknik marmet. Teknik marmet merupakan upaya untuk mengatasi ketidak lancaran ASI secara manual dan membantu secara refleks pengeluaran susu (Milk Ejection Reflex). Teknik Marmet adalah perkembangan kombinasi metode pijat dan stimulasi untuk reflek keluarnya ASI. Teknik marmet adalah cara aman yang dapat dilakukan untuk merangsang pengeluaran ASI pada payudara untuk memproduksi lebih banyak ASI (Widiastuti, Arifah, \& Rahmawati, 2015). Hasil penelitian yang didapatkan nilai sebelum dilakukan intervensi terhadap kelancaran ASI menunjukan nilai rata-rata sebesar 11,3 dengan standar deviasi 2, 177. Sedangkan rata-rata nilai sesudah dilakukan intervensi sebesar 16, 27 dengan standar deviasi 2, 227. Hasil ini menunjukan rata-rata intensitas kelancaran ASI pada responden mengalami peningkatan setelah dilakukan intervensi. Penelitian ini menggunakan uji Wilcoxon yang menunjukan bahwa $\rho$ value $0,000<0,05$ artinya terdapat perbedaan yang signifikan terhadap intensitas kelancaran ASI sebelum dan sesudah dilakukan intervensi.

Hasil penelitian Sinulingga tahun 2017 menyatakan analisa uji statistik perbedaan rata-rata pada kelompok yang dilakukan teknik marmet dengan tidak dilakukan teknik marmet dengan menggunakan uji Mann Whitney $U$ Test didapatkan $p=0.00(p<0.05)$, artinya terdapat perbedaan hasil observasi produksi ASI antara dilakukan dan tidak dilakukan teknik marmet dalam pengosongan payudara pada ibu post partum. Dimana hasil observasi pada penelitian menunjukkan adanya perbedaan selisih rata-rata pada kelompok dilakukan teknik marmet yaitu sebesar 3.80 sedangkan pada kelompok yang tidak dilakukan teknik marmet yaitu sebesar 1.20. Menurut penelitian Widiastuti (2015) hasil analisis uji statistik pada penelitian ini tentang perbedaan teknik marmet dan masase payudara terhadap kelancaran ASI menunjukkan adanya perbedaan secara statistik yaitu teknik marmet lebih memberikan pengaruh dalam kelancaran ASI dibandingkan dengan teknik masase payudara. Hasil penelitian menunjukkan terdapat perbedaan yang signifikan antara produksi ASI sebelum dan sesudah dilakukan teknik tersebut yaitu hasil bahwa seluruh responden (100\%) mendapatkan produksi ASI yang baik $(\geq 7 \mathrm{ml} /$ perah) dengan interval 6 jam setelah dilakukan pretest. Hal ini sejalan dengan penelitian titisari (2016) yang mengatakan bahwa setelah pemberian teknik marmet didapatkan semua responden produksi ASInya lancar (Rahayu, 2014). 
Menurut peneliti teknik marmet merupakan salah satu cara mengatasi ketidaklancaran pemberian ASI secara efektif, manual, aman dan tanpa biaya. Banyak hal yang dapat mengatasi masalah ketidaklancaran ASI salah satunya yaitu teknik marmet.

Teknik marmet sangat mampu mengatasi secara optimal didukung dengan penelitian sebelumnya dan penelitian yang dilakukan peneliti mendapatkan ada pengaruh teknik marmet terhadap kelancaran ASI. Teknik marmet adalah kombinasi pijat yang bisa dilakukan tanpa membutuhkan bantuan orang lain dan bisa dilakukan setiap waktu. Teknik ini sangat dianjurkan pada ibu primipara yang mengalami masalah dalam kelancaran ASI sehingga banyak ibu baru mengalami stress dan ketakutan yang tinggi terhadap pemenuhan kebutuhan ASI pada bayi saat 6 bulan pertama penyebabnya berupa kurangnya hormon prolaktin dan oksitosin yang memiliki peran aktif terhadap kelancaran ASI pada ibu. Peneliti menganjurkan untuk penanganan masalah ini dengan melakukan teknik marmet demi kelancaran ASI. Teknik marmet ini sangat efektif manual, aman dan tanpa biaya, dikarenakan tidak membutuhkan alat yang sulit didapat, hanya dengan menggunakan kedua tangan dan wadah bersih untuk melakukan pemijatan dan pemerahan atau pengosongan payudara sehingga bisa dilakukan semua kalangan ibu.

\section{KESIMPULAN}

Lebih separuh memiliki usia $<30$ tahun $(57$ $\%)$, sebagian besar pendidikan responden perguruan tinggi (40\%), lebih separuh memiliki pekerjaan (60 \%), lebih separuh paritas ibu tertinggi multipara (60 \%), sedangkan mayoritas jenis persalinan ibu adalah normal (77 \%). Sebelum dilakukan intervensi lebih separuh (67\%) mengalami ketidaklancaran ASI. Sesudah dilakukan intervensi mayoritas (86 \%) mengalami kelancaran ASI. Ada pengaruh teknik marmet terhadap kelancaran ASI pada ibu post partum Di Wilayah Kerja Puskesmas Kota Tanjungpinang. Teknik marmet merupakan kombinasi pijat yang sangat efektif, manual, aman dan tanpa biaya. Teknik marmet salah satu upaya yang optimal dalam meransang hormone oksitosin dan prolaktin dalam proses kelancaran ASI.
DAFTAR PUSTAKA

Aprilina, (2016). Kombinasi Breast Care dan Teknik Marmet terhadap Produksi ASI Post Sectio Caesaria di Ruang Flamboyan RSUD Prof. dr. Margono Soekarjo Purwokerto. Jurnal Ilmiah Ilmu Kesehatan, 14(2).

BPS. (2020). Survei Demografi dan Kesehatan Indonesia. Jakarta.

BPS. (2021). Survei Demografi dan Kesehatan Indonesia. Jakarta.

Dahlan, M.S (2014). Statistic Untuk Kedokteran dan Kesehatan Deskriftif, Bivariate dan Multivariate dilengkapi Aplikasi Menggunakan SPSS. Jakarta : Epidemiologi Indonesia.

Dharma, K. (2015). Metodologi Penelitian Keperawatan. Jakarta timur : CV. Trans Info Media

Dinas Kesehatan Kabupaten/Kota SeProvinsi Kepulauan Riau. Profil Kesehatan Provinsi Kepulauan Riau 2019. Tanjung Pinang: Dinas kesehatan Provinsi Kepulauan Riau; 2019.

Dinas Kesehatan Kepulauan Riau, (2019). Profit Kesehatan Tanjungpinang 2020.

Dwi, et al (2019). Skripsi: Pengaruh Pemberian Seryifikat Lulus Air Susu Ibu Terhadap Pencapaian ASI Eksklusif Di Wilayah Puskesmas Godean Kabupaten Sleman, Yogyakarta.

Hamidah, Khusnul. (2016). Skripsi : Pengaruh Teknik Marmet terhadap Produksi ASI Pada Ibu Post Partum di Rumah Sakit PKU Muhammadiyah Gamping. Yogyakarta: Fakultas Ilmu KesehatanAisyiyah.

Hidayati, N. W., Wardita, Y., Suprayitno, E., \& Wicaksono, H. N. (2021). Hubungan Persepsi Kecukupan ASI dengan Perilaku Pemberian ASI pada Bayi 0-6 Bulan di Kecamatan Gayam di Kabupaten Sumenep. Jurnal Keperawatan Terpadu (Integrated Nursing Journal), 3(1), 68-75.

Maryam, et al (2020). Pijat Marmet sebagai Solusi Kelancaran Produksi ASI Ibu Menyusui di Kecamatan Sikur Kabupaten Lombok Timur. Jurnal Ilmu Sosial dan Pendidikan, 4(3), 2656-6753. 
Ningrum, et al (2017). Pengaruh Pemberian Teknik Marmet terhadap Kelancaran Produksi ASI Pada Ibu Post Partum di Wilayah Kerja Puskesmas Sukorame Kota Kediri. Jurnal Ilmu Kebidanan, 5(2), 2579. 7301.

Notoatmodjo, S. (2018). Metodologi Penelitian Kesehatan. Jakarta: PT Rineka Cipta.

Putri dan Utami (2020). Asi dan Menyusui. Yogyakarta : Universitas Aisyiyah Yogyakarta Press.

Rahayu,Rani, dkk. 2014. Metode Memperbanyak Produksi ASI pada Ibu Post Sectio Caesarea dengan Tehnik Marmet dan Breast Care di RSUD Karanganyar. GASTER. Vol. XI. No. 2:56-68.

Rokhamah, R. (2019). Kajian Metode Normal dengan Bantuan Cermin Pada Persalinan Kala II Ibu Primigravida. Jurnal Ilmiah Kesehatan, 7 (2), 2527 8487.

Rosmawaty, R., \& Sukarta, A. (2018). Hubungan Jenis Persalinan dengan Produksi ASI di Rumah Sakit Nene Mallomo Sidrap tahun 2017. Jurnal Kebidanan Dan Keperawatan Aisyiyah.

Rumini, et al (2019). Pengaruh Teknik Marmet terhadap Kelancaran Air Susu Ibu di Desa Nag. Pematang Simalungun Kecamatan Siantar Kabupaten Simalungun. Jurnal Bidan Komunitas 3 (1), 2614-7874.

Salat, S. Y. S., Satriaawati, A. C., \& Permatasari, D. (2021). HUBUNGAN DUKUNGAN KELUARGA DENGAN KEJADIAN POST PARTUM BLUES: The Relationship Between Family Support With Events Of Post Partum Blues. Jurnal Ilmiah Kebidanan (Scientific Journal of Midwifery), 7(2), 116-123.

Sari, et al (2016). Skripsi: Hubungan Stres Psikologis Dengan Kelancaran Produksi ASI Pada Ibu Primipara Yang Menyusui Bayi Usia 1-6 Bulan Di Wilayah Kerja Puskesmas Sukorambi. Jember, Universitas Muhamadiyah Jember.

Setianingrum, et al (2018). Faktor-faktor yang berhubungan dengan pemberian asi pada ibu bekerja. Jurnal Ilmu Keperawata, 10 (3), 2549-8118.

Sinulingga, N.R. (2017). Skripsi : Pengaruh Teknik Marmet dalam Pengosongan Payudara terhadap Produksi ASI Pada
Ibu Post Partum di Klinik Pratama Jannah Kecamatan Percut Sei Tuan Kabupaten Deli Serdang. Medan Politeknik Kesehatan Kemenkes Jurusan Kebidanan.

Sutama, et al (2020). Hubungan Pekerjaan, Paritas, Dan Keterampilan Perawatan Payudara Dengan Perilaku Pemberian ASI Eksklusif. Jurnal Kedokteran, 3(3) 385-394

Titisari. (2016). Perbandingan Efektivitas Kombinasi Teknik Marmet dan Pijat Oksitosin dengan Breast Care Terhadap Produksi ASI Pada Ibu Post Partum. Jurnal Ilmu Kesehatan, 5(1), 87-95.

UNICEF. (2017). Improving Mom and Child Nutrition. New York.

Walyani, E. S. (2015). Asuhan Kebidanan Pada Kehamilan. Yogyakarta : Pustaka Baru.

WHO. (2014). Commission on Ending Childhood Obesity. Geneva: World Health Organization, Departement of Noncommunicable Disease Surveillance.

WHO. (2015). Trends in Maternal Mortality: 1990-2015: estimates from WHO, UNICEF, UNFPA, World Bank Group and the United Nations Population Division.

WHO. (2018). Maternal Mortality. Geneva: Departement of Reproductive Health And Research.

Widiastuti, A., Arifah, S., \& Rahmawati, W. R. (2015). Pengaruh Teknik Marmet dengan Masase Payudara pada Ibu Nifas Tiga Hari Post Partum Terhadap Kelancaran ASI dan kenaikan BB Bayi.

Yundelfa, M. et al (2018) Effect of Duration and Temperature Breastmilk Storage and The Way of Diluting Breastmilk on Protein and Fat Levels in Breastmilk. Jurnal Kebidanan, 3(1), 72-83 